\title{
Currarino syndrome and microcephaly due to a rare 7 q36.2 microdeletion: a case report
}

\author{
Lucia Cococcioni ${ }^{1 *} \mathbb{D}$, Susanna Paccagnini ${ }^{1}$, Elena Pozzi ${ }^{1}$, Luigina Spaccini ${ }^{2}$, Elisa Cattaneo ${ }^{2}$, Serena Redaelli ${ }^{3}$, \\ Francesca Crosti ${ }^{4}$ and Gian Vincenzo Zuccotti ${ }^{1}$
}

\begin{abstract}
Background: Currarino syndrome is a rare condition characterized by presacral mass, anorectal malformation and sacral dysgenesis.

Case presentation: We report the case of a child that presented chronic constipation, encopresis and mycrocephaly. The characteristics were initially compatible with a case of functional constipation and a therapy with polyethylene glycol was prescribed. After a year, because of poor response, a plain abdominal X-ray was performed, detecting sacrum abnormalities. Finally, a CGH-array analysis was performed and a form of Currarino Syndrome caused by a rare 7q36 microdeletion, was diagnosed.

Conclusion: Occult spinal dysraphism should be suspected in case of poor polyethylene glycol responder constipation, even when evident sacral abnormalities on the physical examination are not detected.
\end{abstract}

Keywords: Currarino syndrome, Constipation, 7q36 microdeletion

\section{Background}

Currarino syndrome (CS) is a rare congenital malformation characterized by the triad: presacral mass, anorectal malformation and sacral dysgenesis. Several incomplete forms of CS with variable phenotypes are described, since the only mandatory clinical feature for CS diagnosis is the sacral anomaly [1]. The syndrome was first described in 1981 and approximately 300 cases have been documented in the literature [2]. It is caused by an abnormal separation of the neuroectoderm from the endoderm [3]. It is inherited in an autosomal dominant manner and it is caused by haploinsufficiency of the motor neuron and pancreas homeobox 1 (MNX1) gene on chromosome 7q36 [4]. MNX1 mutations are detected in about $50 \%$ of affected individuals, reaching almost $90 \%$ in familial cases [3]. CS phenotype may include intractable constipation, bowel obstruction, urinary retention, incontinence, frequent urinary tract infections,

\footnotetext{
*Correspondence: lucia.cococcioni@unimi.it

${ }^{1}$ Pediatric Department, "V. Buzzi" Children's Hospital, University of Milan, Via

Castelvetro 32, 20154 Milan, Italy

Full list of author information is available at the end of the article
}

weakness, sensory loss and many others, but more than $33 \%$ of affected children are asymptomatic [2]. We report the case of a child with CS features combined with microcephaly who has a 7q36 microdeletion.

\section{Case presentation}

A 3-year-old female child has been evaluated at our gastroenterological service for persisting constipation and encopresis. The symptoms began when the patient was 18 months old. She was the only child born from non-consanguineous healthy Italian parents. The pregnancy was regular and she was born via vaginal delivery after the 38th week of gestation. Neonatal weight was $3250 \mathrm{~g}\left(50^{\circ}-75^{\circ}\right.$ percentile), length $47 \mathrm{~cm}\left(10-25^{\circ}\right.$ percentile), head circumference $33 \mathrm{~cm}\left(25-50^{\circ}\right.$ percentile). Apgar score was 9-10 -10. Clinical evaluation at birth was normal. Her perinatal period was uneventful. When the child was 26 months old, microcephaly was detected. Cerebral magnetic resonance imaging (MRI) and electroencephalogram (EEG) were performed and both exams resulted normal. Her physical and cognitive development was unremarkable. The family history was negative for 
genetic diseases. On physical examination, abdominal distention and microcephaly (head circumference $45 \mathrm{~cm}$, $<3^{\circ}$ percentile) were the main characteristics detected. The growth was regular, the facial appearance, as well as the sacral and anal regions, were normal. Functional constipation was initially supposed, so toilet training combined with polyethylene glycol (PEG) treatment was prescribed. During the clinical follow-up, constipation and encopresis persisted despite adequate compliance to therapy, so the patient was revaluated at our gastroenterological service. Normal anal sphincter tone and soft stools in rectum were detected at digital rectal examination. Blood tests, particularly thyroid function, celiac disease screening and electrolytes, resulted within normal ranges. On plain abdominal $x$-ray (AXR) fecal impaction was confirmed and partial sacral agenesis and lumbar dextro scoliosis were identified. A lumbosacral MRI was performed and the following features were recorded: "sickle - shaped" sacrum (S2-S5 and coccygeal vertebrae agenesis) with preserved $\mathrm{S} 1$, anterior meningocele, pre sacral teratoma, terminal cord lipoma, low-lying conus medullaris and tethered cord (Fig. 1). To complete the diagnostic evaluation, the urinary tract was studied with abdominal ultrasound and urodynamic test. Both tests resulted normal. As the CS was suspected, MNX1 gene sequencing was performed, but no mutation was detected. Nevertheless, the CGH-array analysis identified a de novo $4.15 \mathrm{Mb}$ deletion of 7q36.2q36.3 region, including $M N X 1$ and $S H H$ genes that are responsible for CS phenotype and microcephaly (Fig. 2) [4-8]. The deletion involves also the DPP6, PAXIP1, HTR5A, EN2 and LMBR1 genes. Because of the association between DPP6 mutations and cardiac arrhythmias, a complete cardiological assessment (electrocardiogram, echocardiogram) was performed, but all these exams resulted in normal range. In addition, it has been reported that the DPP6 gene appears to play a major role in the regulation of proliferation and migration of neurons [9]. Loss-of-function mutations in DPP6 are also associated with microcephaly and intellectual disability. In the last neurological evaluation of our patient, which was performed when the child was 6 years old, mild behavioral abnormalities have been documented. In the literature the EN2 gene has been considered to be a susceptibility gene for autism. Furthermore, mutations of $L M B R 1$ has been associated with polydactyly. However, both of these conditions were not present in our patient. To the best of our knowledge, deletions of PAXIP1 and HTR5A are not associated with any clinical abnormalities.

The patient underwent a neurosurgical operation with the indication of cord untethering. After the surgical treatment, constipation improved and encopresis regressed. Clinical follow-up is still ongoing.

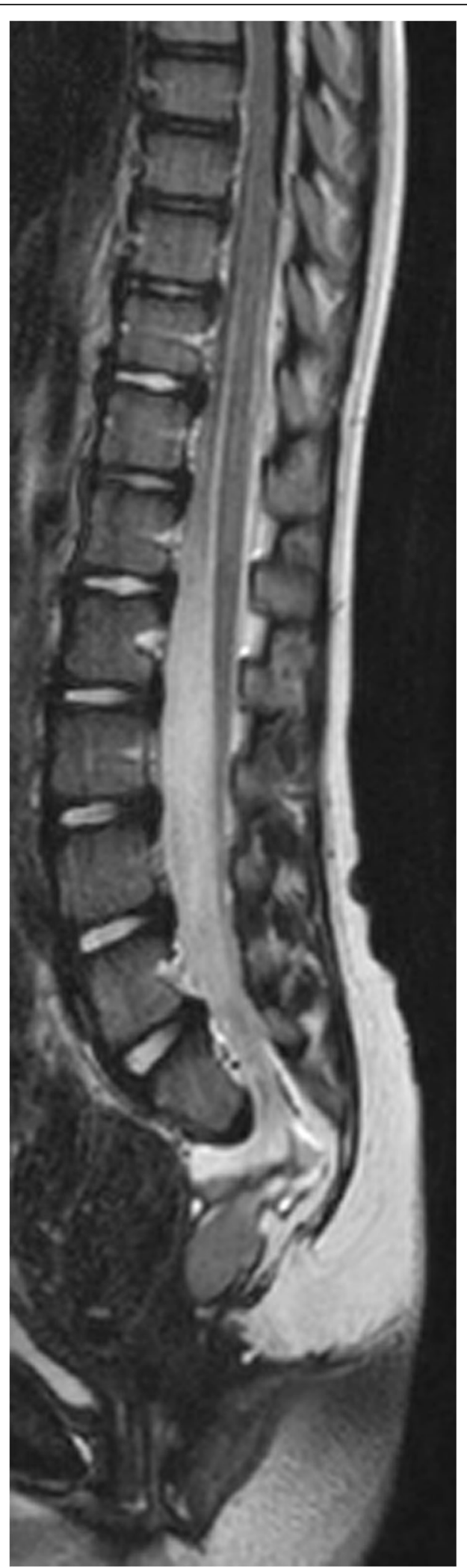

Fig. 1 Sagittal t2- weighted Lumbosacral MRI 


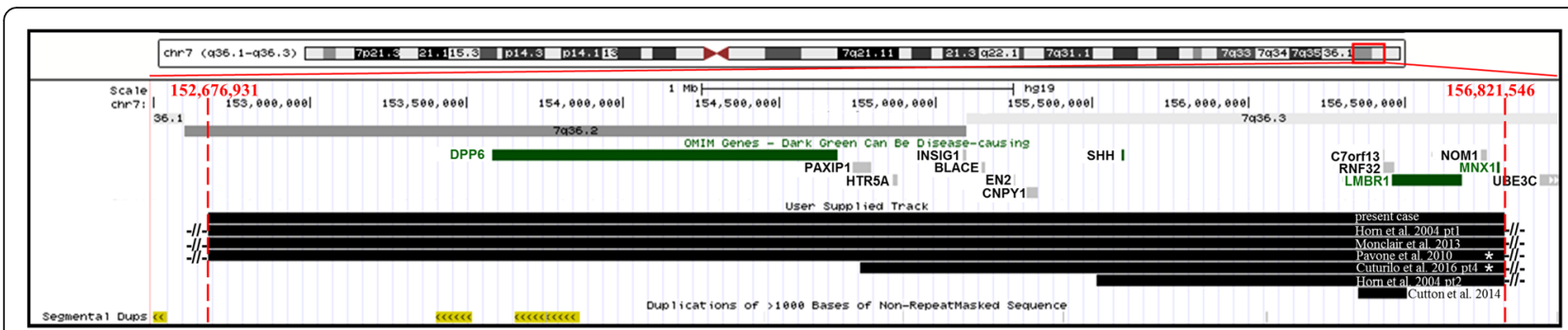

Fig. 2 Mapping of the deletion in 7q36.2-7q36.3 for our patient and comparison with literature [4-8]. Schematic representation of common overlapping deleted region (our case breakpoints are in red). ${ }^{*}=$ two patients described by Pavone et al. [7] and patient 1 described by Cuturilo et al. [4] present a duplication more centromeric and consecutive to the deletion (not shown in the figure)

\section{Discussion}

According to last ESPGHAN and NASPGHAN guidelines about constipation, the history and the clinical characteristics of our patient (regular growth, normal physical examination, the absence of alarm signs and symptoms) were initially compatible with a diagnosis of functional constipation [10]. This disorder is a very common problem during the childhood (estimated prevalence of $3 \%$ worldwide) and it is responsible for more than $95 \%$ of cases of constipation in healthy children older than 1 year of age [11]. Infrequent bowel movements, hard small feces, difficult or painful evacuation of large-diameter stools and fecal incontinence are frequent complaints in children affected by this condition [12].

In our patient, despite toilet training and oral medication, the symptoms persisted. We decided to complete the diagnostic process with blood tests and abdominal $\mathrm{X}$ ray to investigate the presence of fecal impaction and to study the vertebral spine. The radiological test detected an occult spinal dysraphism with partial sacral agenesis. These findings are typical of the Caudal Regression Syndrome (CRS), also known as caudal displasia or Sacral Agenesis Syndrome. This is a very rare disorder of the distal spinal segments with estimated incidence of $0.1-0.25$ cases per 10,000 normal pregnancies. In addition, a 200 times increased incidence has recorded in infants of diabetic mothers, where it occurs in about 1 in 350 infants [13]. The syndrome is the result of a neural tube defect that occurs before 28 days of gestation. While the exact etiology and pathogenetic mechanism are poorly understood, several factors such as maternal diabetes, vascular hypoperfusion, drugs (i.e. minoxidil, thripethoprim/ sulphamethoxazole, chemicals, fat solvents and appetite suppressants) and genetic predisposition (i.e. VANGL1 gene mutation) have been suggested to have a causative role [14]. The CRS may range from absent coccyx as an isolated finding without neurological sequelae, to sacral or lumbosacral agenesis. Additional complications of the genitourinary, gastrointestinal and respiratory systems may occur. The CRS spectrum can be categorized in different types. In fact, several classifications are available based on the amount of the sacrum remaining, the characteristics of the articulation between the spine and pelvis and the presence or absence of myelomenigocele [15-17]. The CS, historically known as "Currarino's triad", is considered a form of CRS characterized by the classic triad of presacral mass, sacral bone defect and anorectal malformation. CS was suspected in our patient due to the sacrum peculiar morphology and the presacral mass, shown by the spine MRI. The specific sacral anomaly characterized by partial sacral agenesis with intact first sacral vertebra ("sickle-shaped sacrum"), is typical of this syndrome, although other associated congenital malformations and/or developmental delay have been reported. CS phenotypic expression is variable, some patient being asymptomatic while others presenting the complete triad. Autosomal dominant mutations in the MNX1 gene cause nearly all familial and $30 \%$ of sporadic cases. Furthermore, deletions of the $7 \mathrm{q} 36$ region have been reported in association with CS [3, 18]. In addition, sporadic cases of CS with a partial duplication of the long arm of the chromosome 3 but no MNX1 mutation have been reported in the literature [19]. Despite the extreme phenotipic variability observed in patients carrying the same mutation, as well as the incomplete penetrance in familiar cases, recent studies have tried to demonstrate an association between mutation type and severity of the phenotype [20,21].

The analysis of Merello E. et al. [20], that reported a series of CS patients carrying only intragenic mutations, has failed to establish a clear genotype-phenotype correlation. On the other hand, a more recent multicentre Italian study has reported that the presence of a MNX1 anomaly, such as an intragenic mutation or a deletion, was associated to a more severe CS phenotype compared to cases in which no mutation was identified [21]. Moreover, according to Cuturilo G. et al. [4], intragenic mutations of MNX1 are observed more frequently in patients with the classic Currarino triad and regular growth, normal intellect and facial appearance. Instead, CS phenotypes characterized by growth delay and/or facial dimorphism and/or intellectual disability are often due to deletions of long arm of chromosome 7 containing $M N X 1$ [4]. Indeed, MNX1 gene seems to be the main responsible factor for the expression and severity of the 
CS triad, while the associated anomalies appear to be determined by contiguous genes [21].

We performed MNX1 sequencing first, but it resulted normal. Considering the co-occurrence of a CS-like phenotype and microcephaly reported in previous patients [7], we performed the $\mathrm{CGH}$-array analysis. A microdeletion, i.e. a relative small deletion involving less than $5 \mathrm{Mb}$ of a chromosomal segment, including MNX1 and $S H H$ genes, responsible for the patient's phenotype was identified by the last test. To the best of our knowledge, this is one of the few reported cases with features of an incomplete form of CS and microcephaly due to a $7 q 36$ microdeletion. As well as our case, patients with deletion involving the same region (Fig. 2) has shown the elements of Currarino triad and microcephaly as main features. However, the previous cases have reported also growth retardation, facial dismorphies, brain abnormalities and other anomalies such as urogenital malformation [4-8]. These characteristics were not present in our patient, underlining the extreme phenotypic variability of CS, as reported in the literature.

\section{Conclusion}

Occult spinal dysraphism should be suspected in case of poor PEG responder constipation, even when evident sacral abnormalities on the physical examination are not detected. In this case, instrumental tests (i.e. abdominal $\mathrm{x}$-ray/MRI) should be performed. Particularly abdominal $\mathrm{x}$-ray is a first level test, cost-effective and easy to perform which can give useful information about rachis morphology.

When a CS phenotype is associated with malformations not included in the classic Currarino's triad, the CGH-array is recommended as the test of choice, since the presence of a $7 \mathrm{q} 36$ deletion is more likely. If microdeletions or microduplications are not identified, MNX1 gene sequencing should be considered.

\section{Abbreviations}

AXR: Abdominal x ray; CS: Currarino syndrome; EEG: Electroencephalogram; MRI: Magnetic resonance imaging

\section{Availability of data and materials}

Data sharing not applicable to this article as no datasets were generated or analysed during the current study.

\section{Authors' contributions}

LC collected the information, drafted the initial manuscript. LS, EC, SR and FC performed molecular genetic analyses, critically reviewed and revised the manuscript. SP, EP and GVZ critically reviewed and revised the manuscript. All authors read and approved the final manuscript.

Ethics approval and consent to participate

Not applicable according to our Institutional Research Ethic Boards.

\section{Consent for publication}

Consent to publication was obtained from parents.

\section{Competing interests}

The authors declare that they have no competing interests.

\section{Publisher's Note}

Springer Nature remains neutral with regard to jurisdictional claims in published maps and institutional affiliations.

\section{Author details}

${ }^{1}$ Pediatric Department, "V. Buzzi" Children's Hospital, University of Milan, Via Castelvetro 32, 20154 Milan, Italy. ${ }^{2}$ Genetic Service, Department of Obstetrics and Gynecology, "V. Buzzi" Children's Hospital, University of Milan, Milan, Italy. ${ }^{3}$ School of Medicine and Surgery, University Milano-Bicocca, Monza, Italy.

${ }^{4}$ Medical Genetic Laboratory, Clinical Pathology Department, S. Gerardo Hospital, Monza, Italy.

Received: 26 January 2018 Accepted: 18 May 2018

Published online: 25 May 2018

\section{References}

1. Pio L, Piatelli G, Rossi A, Scarsi P, Merello E, Capra V, Cama A, Buffa P, Torre M. Urological outcome in patients with Currarino syndrome. J Pediatr Surg. 2014; https://doi.org/10.1016/j.jpedsurg.2014.05.038.

2. Buyukbese Sarsu S, Parmaksiz ME, Cabalar E, Karapur A, Kaya C. A very rare cause of anal atresia: Currarino syndrome. J Clin Med Res. 2016; https://doi. org/10.14740/jocmr2505w.

3. Crétolle C, Pelet A, Sanlaville D, Zérah M, Amiel J, Jaubert F, Révillon Y, Baala L, Munnich A, Nihoul-Fékété C, Lyonnet S. Spectrum of HLXB9 gene mutations in Currarino syndrome and genotype-phenotype correlation. Hum Mutat. 2008; https://doi.org/10.1002/humu.20718.

4. Cuturilo G, Hodge JC, Runke CK, Thorland EC, Al-Owain MA, Ellison JW, Babovic-Vuksanovic D. Phenotype analysis impacts testing strategy in patients with Currarino syndrome. Clin Genet. 2016; https://doi.org/10. $1111 /$ cge. 12572

5. Horn D, Tönnies H, Neitzel H, Wahl D, Hinkel GK, von Moers A, Bartsch O. Minimal clinical expression of the holoprosencephaly spectrum and of Currarino syndrome due to different cytogenetic rearrangements deleting the sonic hedgehog gene and the HLXB9 gene at 7q36.3. Am J Med Genet A. 2004;128A(1):85-92.

6. Monclair T, Lundar T, Smevik B, Holm I, Ørstavik KH. Currarino syndrome at Rikshospitalet 1961-2012. Tidsskr Nor Laegeforen. 2013; https://doi.org/10. 4045/tidsskr.13.0352

7. Pavone P, Ruggieri M, Lombardo I, Sudi J, Biancheri R, Castellano-Chiodo D, Rossi A, Incorpora G, Nowak NJ, Christian SL, Pavone L, Dobyns WB. Microcephaly, sensorineural deafness and Currarino triad with duplicationdeletion of distal 7q. Eur J Pediatr. 2010; https://doi.org/10.1007/s00431-0091061-6.

8. Coutton C, Poreau B, Devillard F, Durand C, Odent S, Rozel C, Vieville G Amblard F, Jouk PS, Satre V. Currarino syndrome and HPE microform associated with a 2.7-Mb deletion in 7q36.3 excluding $\mathrm{SHH}$ gene. Mol Syndromol. 2014; https://doi.org/10.1159/000355391.

9. Liao C, Fu F, Li R, Yang WQ, Liao HY, Yan JR, Li J, Li SY, Yang X, Li DZ. Loss-of-function variation in the DPP6 gene is associated with autosomal dominant microcephaly and mental retardation. Eur J Med Genet. 2013; https://doi.org/10.1016/j.ejmg.2013.06.008.

10. Tabbers MM, DiLorenzo C, Berger MY, Faure C, Langendam MW, Nurko S, Staiano A, Vandenplas Y, Benninga MA. Evaluation and treatment of functional constipation in infants and children: evidence-based recommendations from ESPGHAN and NASPGHAN. J Pediatr Gastroenterol Nutr. 2014; https://doi.org/10.1097/MPG.0000000000000266.

11. Loening-Baucke V. Prevalence, symptoms and outcome of constipation in infants and toddlers. J Pediatr. 2005; https://doi.org/10.1016/j.jpeds. 2004.10.046.

12. Rubin GP. Childhood constipation. Am Fam Physician. 2003; (67 Suppl 5):1041-2.

13. Sen KK, Patel M. Caudal regression syndrome. Med J Armed Forces India. 2007; https://doi.org/10.1016/S0377-1237(07)80071-2.

14. Balioğlu MB, Albayrak A, Atici Y, Tacal T, Kargin D, Kaygusuz MA, Yildirim CH, Erdoğan H, Bursali A, Taşdemiroğlu E. Caudal regression syndrome (sacral agenesis) with associated anomalies. J Turkish Spinal Surg. 2013;24:191-8.

15. Renshaw TS. Sacral agenesis. J Bone Joint Surg Am. 1978 Apr;60(3):373-83. 
16. Pang D. Sacral agenesis and caudal spinal cord malformations. Neurosurgery 1993;32(5):755-78. discussion 778-9

17. Guille JT, Benevides R, DeAlba CC, Siriram V, Kumar SJ. Lumbosacral agenesis: a new classification correlating spinal deformity and ambulatory potential. J Bone Joint Surg Am. 2002;84-A(1):32-8.

18. Garcia-Barceló MM, Lui VC, So MT, Miao X, Leon TY, Yuan ZW, Ngan ES, Ehsan T, Chung PH, Khong PL, Wong KK, Tam PK. MNX1 (HLXB9) mutations in Currarino patients. J Pediatr Surg. 2009; https://doi.org/10.1016/j.jpedsurg. 2009.03.039.

19. Dworschak GC, Crétolle C, Hilger A, Engels H, Korsch E, Reutter H, Ludwig M. Comprehensive review of the duplication $3 q$ syndrome and report of a patient with Currarino syndrome and de novo duplication 3q26.32-q27.2. Clin Genet. 2017; https://doi.org/10.1111/cge.12848.

20. Merello E, De Marco P, Ravegnani M, Riccipetitoni G, Cama A, Capra V. Novel MNX1 mutations and clinical analysis of familial and sporadic Currarino cases. Eur J Med Genet. 2013 https://doi.org/10.1016/j.ejmg. 2013.09.011.

21. Costanzo S, Spaccini L, Pio L, Mattioli G, Virgone C, Dall'Igna P, lacobelli B, Inserra A, Brisighelli G, Fagnani AM, Leva E, Giannotti G, Cheli M, Frumento P, Riccipetitoni G. Currarino syndrome: does the presence of a genetic anomaly correlate with a more severe phenotype? A multicentre study. J Pediatr Surg. 2017 Oct;52(10):1591-6. https://doi. org/10.1016/j.jpedsurg.2017.06.012

Ready to submit your research? Choose BMC and benefit from:

- fast, convenient online submission

- thorough peer review by experienced researchers in your field

- rapid publication on acceptance

- support for research data, including large and complex data types

- gold Open Access which fosters wider collaboration and increased citations

- maximum visibility for your research: over $100 \mathrm{M}$ website views per year

At BMC, research is always in progress.

Learn more biomedcentral.com/submissions 